\title{
Self-Regulated Learning Strategies and Their Effects on Math Performance of Pre-University International Students in Malaysia
}

\author{
Tang Eng Loong \\ Jalan Universiti, Bandar Sunway, Petaling Jaya, Selangor, Malaysia \\ lawrencet@sunway.edu.my
}

\begin{abstract}
The study examined any differences in self-regulated learning (SRL) strategies between two groups of international students in the Monash University Foundation Year (MUFY) program in Malaysia, in which one group of 58 international students in their first semester, and another group of 18 international students in their second and third semesters. It followed by examining the effect of the use of SRL strategies on math performance for both groups. The Learning and Study Strategies Inventory (LASSI) was used to measure the use of SRL strategies among international students, and the final score of the most manageable mathematical subject was used to measure their math performance. The result indicated that first-semester international students used as many SRL strategies as second- and thirdsemester international students, and no significant difference in math performance between the groups was found. The result also revealed that attitude towards academic tasks; motivation level and test taking strategies were positively associated with math performance of first-semester international students, while anxiety towards tests, attitude towards academic tasks and test taking strategies were positively associated with second- and third-semester international students' math performance. Moreover, math performance of first-semester international students was significantly predicted by attitude towards academic tasks and test taking strategies, but second- and third-semester international students' math performance was not significantly predicted by any SRL strategies.
\end{abstract}

Key words: Pre-university, international students, math performance, self-regulated learning (SRL), correlation

\section{Introduction}

The number of international students at private institutions of higher education in Malaysia has been increased over the past few years. There were 50,679,58,294, and 62,705 international students at Malaysian private institutions of higher education in 2008, 2009, and 2010 respectively (Ministry of Higher Education, 2008, 2009, 2010). The increase in the number of international students was due to various higher education reforms in the 1990s such as the privatization of higher education under the Private Higher Educational Act 1996 (Sivalingam, 2006). The reforms were considered necessary in order to turn the nation into an education hub in the region and were crucial to the nation's economic growth (Sirat, 2006). The economic impact by international students can be seen in many education-exporting countries. For instance, international students in Canada spent about $\$ 6.5$ billion, which included tuition fee, and created more than 83,000 jobs in 2008 (Roslyn Kunin \& Associates, 2009). Many studies on international students in Malaysia have examined their choice criteria in selecting the nation as their destination of higher education (British Council, 2008; Jani \& Zubairi, 2010; Baharun et al., 2011; Dahari \& Abduh, 2011). For instance, the top three choice criteria rated by international students were international recognition of qualification, low tuition fee and opportunity to make international contact (Jani \& Zubairi, 2010). In addition, the event of September 11 caused students from the Middle East to cancel their plan to go to the US for education, and chose Malaysia as their destination of higher education (Sirat, 2008). These studies are considered important to the higher education institutions and the nation on the best ways to attract students that are more international.

International students' academic performance is important in addition, as their primary goal to go overseas is to get qualification. There is still lack of research focuses on their academic performance as well as factors that influence their academic performance in Malaysia. A Malaysian study proposed a theoretical model of explaining international students' academic performance by demographic factors, English proficiency, social support and personality variables (Yusoff \& Chelliah, 2010). One important factor not included in the Yusoff and Chelliah's model is self-regulated learning (SRL) as one previous study on Malaysian undergraduate students at a local university found that the use of SRL strategies had some influence on their academic performance. More specifically, their cumulative grade point average 
was positively associated with attitude towards studying, but negatively associated with achievement motivation (Bakar et al., 2010). It suggests that the use of SRL strategies may have some influence on international students' academic performance as well. This is also in line with an issue raised in Western countries that international students learning under the Western academic standards may develop complex metacognition and adaptive methods in order to achieve academic success (Valiente, 2008). However, these studies are directly related to undergraduate students. Very little has been known about international students' academic performance and factors that influence their academic performance at pre-university level in general. Most international students at private higher education institutions in Malaysia choose a pre-university program as their pathway to do degree courses. There are many preuniversity programs offered such a pathway, one of them is the Monash University Foundation Year (MUFY) program. There were 729 students in the MUFY program at a private institution in September 2011. Of this total, $25.2 \%$ were international students.

Monash University Foundation Year: The program is considered as year zero of Monash University. It is to be completed in two semesters, but students are allowed to complete the program in more than two semesters. Three of the subjects offered are mathematical subjects, in which Fundamental Mathematics is one of them. The mathematical subject is equivalent to Year 11 mathematics, and it is the easiest one as compared to the other two mathematical subjects. The selection of the three mathematical subjects will determine the field of study at the university. Fundamental Mathematics is one of pre-requisites for many degree courses offered in the field of business studies. All subjects consist of Part A and Part B. Fundamental Mathematics A is normally taken by first-semester students and is taken by a small group of students who are in their second and third semesters.

The Present Study: The number of international students in the classes of Fundamental Mathematics A has been increased in the recent years. Because of the increase of international students, it raises challenges to academic staff to engage them in learning as their educational and cultural backgrounds are widely diversified. One initiative effort to understand how they learn under the new academic environment is to examine their use of SRL strategies. It provides opportunity to academic staff to help them to adjust themselves to the new academic setting and to achieve academic success. International students in their first semester are anticipated to use less SRL strategies in their learning of this subject as the academic setting is new to them. On the other hand, second- and third-semester international students are more familiar to academic environment and are expected to use more SRL strategies than first-semester international students do. Furthermore, the two groups may emphasize different SRL strategies in their efforts to do well in the subject. Because of different emphasis on the use of SRL strategies between the two groups, SRL strategies may have different effects on the grade of the mathematical subject. The study is conducted to answer the matters raised. The specific objectives are listed as follows:

- To compare math performance between the two groups.

- To determine any differences in SRL strategies between the two groups.

- To determine the correlations between math performance and SRL strategies for each of the two groups.

- To determine which SRL strategies are the significant predictors of their math performance for each of the two groups.

\section{Literature Review}

Self-Regulated Learning (SRL): SRL is described as the process by which learners personally activate and sustain cognitions, affects, and behaviors that are systematically oriented towards achieving learning goals (Schunk \& Zimmerman, 2008), and self-regulated learners are described as self-initiators who exercise choice of control over the methods needed to obtain the learning goals they set for themselves (Purdie et al., 1996). There are multiple definitions of SRL and many theoretical models that related to SRL in the field of educational psychology. Some other studies used different names to define the same learning phenomenon. Metacognition and self-regulation were other names that frequently appeared in the past literature. It was reported that SRL, metacognition, and self-regulation were not separate concepts, but they were subtypes of the same abstract learning phenomenon (Kaplan, 2008).

SRL Strategies and Overall Academic Performance: Empirical evidence has long established the importance of SRL strategies in predicting overall academic performance for general student populations. The grade point average (GPA) among first-year students at college was positively correlated with 
attitude, motivation, anxiety, concentration, information processing and test strategies (Hulick \& Higginson, 1989). Another study examined the differences on the use of SRL strategies between matriculation and university students (Yip \& Chung, 2005). Both authors found that selecting main idea, attitude, study aids, motivation, time management, self-testing and test strategies were significant indicators for their mean GPA of matriculation students, and for university students, concentration and motivation were significant indicators of their mean GPA. A study on the use of SRL strategies among undergraduate students without learning disability found that their GPA was positively predicted by motivation (Reaser et al., 2007). A large-scale study found that study motivation, study skills and study attitudes were positively correlated with their GPA among college students, and academic specific anxiety was found to be negatively correlated with their academic performance (Credé \& Kuncel, 2008). However, past literature on the influence of SRL strategies on international students' academic performance was extremely rare. A study on freshman international students found that motivation, selftesting and test strategies were positively correlated with their GPA (Stoynoff, 1997).

SRL Strategies and Math Performance: The use of SRL strategies may be varied in different academic subjects. Junior high school students in classes of three academic subjects, namely mathematics, English and social studies, were reported to be different in value and interest for self-efficacy, academic tasks and test anxiety (Wolters \& Pintrich, 1998). The demand for cognitive ability in mathematical subjects is certainly higher than those of linguistics and social science. A study on senior (Year 12) mathematics students found that many students did not use efficient and appropriate SRL strategies, and they were expected to be unable to cope with academic subjects such as mathematics that demand highly on cognitive ability (Anthony, 1996). There were limited empirical studies that focused on the association between the use of SRL strategies and students' math performance. Motivation was found to be a significant predictor for undergraduates' performance in immediate algebra (Belcheir, 2002). Math performance among first-year college students majoring in mathematics was positively correlated with time management, motivation, concentration and study aids, but negatively correlated with anxiety (MacNamara \& Penner, 2005). Motivation, concentration, information processing and self-testing were reported to be significantly predictors for the final grade of an online college math course (Wadsworth et al., 2007). In a study, the use of SRL strategies (consisted of awareness, self-checking, planning, cognitive strategy use and effort) was positively correlated with math performance among mathematically gifted high school students (Malpass et al., 1999). Furthermore, the grade of a test of a geometry course achieved in the early of a semester among high school students was significantly predicted by metacognition strategies and effort management, while the grade of another test of the geometry course obtained in the later of the semester was significantly predicted by metacognition strategies (Pokay \& Blumenfeld, 1990).

\section{Methodology}

Sample: A total of 76 international students (39 males, 37 females) in all classes of Fundamental Mathematics An over four semesters voluntarily participated in the study. There were 25, 11, 21, and 19 international students in July 2010, August 2010, July 2011, and August 2011 semester respectively. Students in all the classes of the subject in July and August 2010 semesters were taught by the same instructor, and students in all the math classes in July and August 2011 semesters were taught by two instructors.

Material: The material consisted of two parts:

The first part was questions related to demographic and educational information. The questions were gender, age, nationality, secondary school examination and number of semesters in the program.

The second part contained the Second Edition of the LASSI (Weinstein, Palmer \& Shulte, 2002), which was employed to assess international students' SRL strategies in ten scales. There were 80 items in the inventory. Each item response was obtained on a 5-point likert scale, ranged from 1 (not at all typical of $m e$ ), 2 (not very typical of me), 3(somewhat typical of me), 4(fairly typical of me), and 5 (very much typical of me). The descriptions of the ten scales together with a sample item and their internal consistency reliability coefficients (Cronbach's alpha) were given as below:

- Anxiety - feelings of anxious towards tests and school despite being well prepared. E.g. 'I feel very panicky when I take an important test' $(\alpha=.87)$

- Attitude - willing to work on academic tasks given; attitude towards school. E.g. 'I am able to study subjects I do not find interesting' $(\alpha=.77)$ 
- Concentration - able to pay attention to, concentrate on, and think about the learning materials. E.g. 'I find it difficult to maintain my concentration while doing my coursework' $(\alpha=.86)$

- Information Processing - ability to use verbal and imaginational elaboration; strategies of organizing and interrelating information; skills of comprehending, reasoning, and use of logic. E.g. 'When I am studying a topic, I try to make everything fit together logically' $(\alpha=.84)$

- Motivation - desire and willingness to work hard; level of motivation and incentive for school; self-discipline. E.g. 'When work is difficult, I either give up or study only the easy parts' $(\alpha=.84)$

- Self-Testing - regular review of course materials; checks of the comprehension level attained; preparation for the lesson. E.g. 'I review my notes before the next class' $(\alpha=.84)$

- Selecting Main Ideas - able to figure out the key ideas in the course materials and focus on these during studying. E.g. 'I have difficulty identifying the important points in my reading' $(\alpha=.89)$

- Study Aids - able to use various aids and techniques to support learning; use of key words, examples, headings, and diagrams to help learning. E.g. 'My underlining is helpful when I review text material' $(\alpha=.73)$

- Time Management -create and use time schedules effectively, and able to manage their study time. E.g. 'I find it hard to stick to a study schedule' $(\alpha=.85)$

- Test Strategies - possess knowledge of different types of tests and the necessary preparation for them. E.g. 'When I take a test, I realize I have studied the wrong material' $(\alpha=.80)$

Math Assessment: These were the topics for Fundamental Mathematics A: Number Systems; Fractions, Decimals and Percentage; Algebra; Ratio and Proportion; Sequence and Series; Business Mathematics. The final score of the subject was used to assess students' math performance. The assessment format had two major components for all the four semesters involved: coursework mark (40\%), which was calculated based on five topic tests, and final exam (60\%). The weightage of $8 \%$ was given to each topic test. All topic tests and final exams consisted of subjective questions. The following was the grade distribution: Fail (F) (49\% or below), Pass (P) (50\% to 59\%), Credit (C) (60\% to 69\%), Distinction (D) $(70 \%$ to $79 \%)$ and High Distinction (HD) (80\% or above). In this study, the pass rate was defined as the percentage of students achieving grade 'P' or better.

Procedure: It involved all the math classes of July 2010, August 2010, July 2011 and August 2011 semesters. For each of these classes, their respective instructor briefed international students on the purpose of the survey. Only international students who were interested in the survey were given an informed consent form and the survey material. Majority of these international students completed and returned both the consent form and the survey material to their instructors in classrooms on the same day. A small group of international students cannot complete the survey material in classrooms, and they were asked to bring it to their math classes the following day. All these surveys were carried out one or two weeks before their semesters end.

Data Collection: For all math classes in each of July 2010, August 2010, July 2011 and August 2011 semesters, the scores of five tests were recorded throughout their semester, and the score of their final exam was also recorded at the end of their semester. The course work mark was calculated with a weightage of $8 \%$ was given to each of five topic tests. The course work mark and the score of final exam were then entered into the template provided by Monash College in the end of each semester. Students' final math score was automatically calculated in the template provided. Once the final scores of the subject were confirmed by Monash College, international students' demographic and educational information, their item responses in the survey material and their confirmed final math scores were then entered into the SPSS version 19. The process of collecting data in this study took about one and a half years to be completed.

Data Analysis: The analysis started with the Independent Samples t-test to assess math performance between the semester groups. It followed by the Multivariate Analysis of Variance (MANOVA) to test the hypothesis of differences between the two semester groups on the 10 LASSI scales, and the Independent Samples t-test to assess their difference in each LASSI scale. The Pearson correlation analysis was employed to investigate the inter-correlation between math performance and SRL strategies for each of the two groups of international students. Finally, the multiple linear regression analysis with the least square method was used to determine significant predictors of international students' math performance for each of the groups. In the regression analysis, the dependent variable was the final score of the subject, whereas the independent variables were the LASSI scales. 


\section{Results}

Descriptive Statistics: 58, 13, and 5 international students are in their first, second, and third semester respectively when the surveys are conducted in all the four semesters. Their ages range from 16 to 24 years with $\mathrm{M}=18.16$ and $\mathrm{SD}=.91$. They come from 26 countries and their numbers are as shown below: Indonesia (10), Sri Lanka (8), Bangladesh (7), Pakistan (5), China (4), Saudi Arabia (4), Uganda (4), Bahrain (3), Kazakhstan (3), Kenya (3), Maldives (3), South Korea (3), Vietnam (3), Iran (2), Nigeria (2), Sudan (2), Bosnia (1), Guinea (1), India (1), Jordan (1), Mauritius (1), Singapore (1), Taiwan (1), Tajikistan (1), Thailand (1) and Zimbabwe (1). They are then summarized according to geographical regions, which can be seen in Table 1 .

Table 1: Composite of International Students according to Geographical Regions

\begin{tabular}{lll}
\hline Geographical Region & Frequency & Percentage \\
\hline South Asia & 24 & 31.6 \\
Asia Pacific & 23 & 30.3 \\
Africa & 14 & 18.4 \\
Middle East & 10 & 13.2 \\
Central Asia & 4 & 5.3 \\
Others & 1 & 1.2 \\
Total & 76 & 100.0 \\
\hline
\end{tabular}

Their educational backgrounds are as shown below: General Certificate of Education (GCE) O-Level (26.3\%), International General Certificate of Secondary Education (IGCSE) O-Level (11.8\%), Ujian Akhir Nasional (UAN) or National Final Exam (9.2\%), Secondary School Certificate (SSC) (3.9\%), Uganda Advanced Certificate of Education Exam (UACE) (3.9\%), General Certificate of Secondary Education (GCSE) 0-Level (2.6\%), Hui Kao or National Senior High School Graduation Examination (2.6\%), others $(30.5 \%)$ and no response $(9.2 \%)$. Descriptive statistics in Table 2 show that the data are normally distributed, with acceptable skewness and kurtosis values. All the LASSI scales show acceptable levels of reliability, except Information Processing, Study Aids and Time Management (see Table 2).

Table 2: Results of Descriptive Statistics

\begin{tabular}{lllllll}
\hline Variable & Min.-Max. & M & SD & Skew. & Kurt. & Cronbach $\boldsymbol{\alpha}$ \\
\hline ANX & $11-38$ & 23.09 & 5.90 & .36 & -.06 & .76 \\
ATT & $14-39$ & 28.29 & 6.14 & -.48 & -.36 & .77 \\
CON & $14-39$ & 25.46 & 5.06 & .07 & -.24 & .72 \\
INP & $19-40$ & 27.97 & 4.82 & .35 & -.73 & .69 \\
MOT & $16-40$ & 28.68 & 5.04 & -.01 & -.33 & .75 \\
SFT & $8-38$ & 24.32 & 5.22 & .09 & .75 & .70 \\
SMI & $13-40$ & 27.74 & 5.42 & .10 & -.15 & .80 \\
STA & $13-40$ & 25.26 & 5.08 & .26 & .27 & .66 \\
TMT & $15-39$ & 25.00 & 4.10 & .21 & 1.24 & .67 \\
TST & $14-40$ & 26.46 & 5.48 & .31 & .32 & .78 \\
FMS & $3-99$ & 62.75 & 23.94 & -.65 & -.38 & -
\end{tabular}

ANX = Anxiety; $A T T$ = Attitude; $C O N=$ Concentration; INP = Information Processing; $M O T=$ Motivation; SFT = Self-Testing; SMI = Selecting Main Ideas; STA = Study Aids; TMT = Time Management $;$ TST = Test Strategies; FMS = Final Math Score.

Math Performance between Two Groups: The grade distribution for first-semester international students is as follows: 15 F's, 7 P's, 7 C's, 9 D's and 18 HD's. For second- and third-semester international students' grade distribution is shown as below: 4 F's, 2 P's, 1 C's, 4 D's and 5 HD's. Four international students do not have grades due to the students are absent from their final exam. The pass rate for firstsemester international students and second- and third-semester international students is $73.7 \%$ and $75.0 \%$ respectively. $\mathrm{M}=.74$ and $\mathrm{SD}=.45$ for the pass rate of the first group, and $\mathrm{M}=.75$ and $\mathrm{SD}=.45$ for the pass rate of the second group. $\mathrm{M}=62.34$ and $\mathrm{SD}=25.02$ for the final math score of the first group, and $\mathrm{M}=64.19$ and $\mathrm{SD}=20.41$ for the final math score of the second group. The statistics of the Independent Samples t-test on the pass rate between the two groups are: $\mathrm{t}(70)=-.271, \mathrm{p}=.788$, and the statistics of Independent Samples t-test on the mean of the final math score between the two groups are: $t(70)=$ $.141, \mathrm{p}=.888$. The results of the two t-tests show that math performance for the two groups are not significantly different based on the pass rate and the mean of final math score at the .05 level. 
Use of SRL Strategies between Two groups: The descriptive statistics (mean and standard deviation) for the LASSI scales for each of the two semester groups, which can be seen in Table 3. All the LASSI scales of second- and third-semester international students are higher than first-semester international students, except Test Strategies. The result of MANOVA with Wilks' Lambda of .928 and F $(10,65)=.503, p$ $=.882$, reveals no significant differences between the two groups on the LASSI scales at the .05 level. The results of a series of Independent Samples t-tests further confirm that no significant difference between the two groups for each LASSI scale at the .05 level (see Table 3).

Table 3: Descriptive Statistics of LASSI Scales for First-Semester and Second- and Third-Semester International Students, and Independent Samples t-test

\begin{tabular}{|c|c|c|c|c|c|c|}
\hline \multirow[t]{2}{*}{ Variable } & \multicolumn{2}{|c|}{$1^{\text {st }}$ Semester } & \multicolumn{2}{|c|}{$2^{\text {nd }} \& 3^{\text {rd }}$ Semesters } & \multirow[t]{2}{*}{$\mathrm{t}(70)$} & \multirow[t]{2}{*}{$\mathrm{p}$} \\
\hline & $\mathrm{M}$ & SD & $\mathrm{M}$ & SD & & \\
\hline ANX & 22.95 & 5.50 & 23.56 & 7.20 & -.379 & .706 \\
\hline ATT & 28.07 & 6.30 & 29.00 & 5.74 & -.559 & .578 \\
\hline $\mathrm{CON}$ & 25.26 & 4.97 & 26.11 & 5.44 & -.622 & .536 \\
\hline INP & 27.59 & 4.87 & 29.22 & 4.60 & -1.262 & .211 \\
\hline MOT & 28.22 & 5.21 & 30.17 & 4.26 & -1.438 & .155 \\
\hline SFT & 23.79 & 5.22 & 26.00 & 4.99 & -1.582 & .118 \\
\hline SMI & 27.72 & 5.72 & 27.78 & 4.47 & -.036 & .971 \\
\hline STA & 24.88 & 4.93 & 26.50 & 5.51 & -1.185 & .240 \\
\hline TMT & 24.60 & 3.91 & 26.28 & 4.55 & -1.526 & .131 \\
\hline TST & 26.47 & 5.46 & 26.44 & 5.70 & .014 & .989 \\
\hline
\end{tabular}

Table 4: Correlations among LASSI Scales and Final Math Score for International Students in First Semester and Those in Second and Third Semesters

\begin{tabular}{|c|c|c|c|c|c|c|c|c|c|c|c|}
\hline Variable & Semester & 2. & 3. & 4. & 5. & 6. & 7. & 8. & 9. & 10. & 11. \\
\hline \multirow[t]{2}{*}{ 1. ANX } & $1^{\text {st }}$ & $.28^{*}$ & $.60 * *$ & .10 & $.36 * *$ & -.13 & $.52^{* *}$ & -.04 & .22 & $.56^{* *}$ & .09 \\
\hline & $2^{\text {nd }} \& 3^{\text {rd }}$ & .34 & .11 & $-.51^{*}$ & -.10 & -.42 & .39 & -.44 & -.10 & $.60 * *$ & $.56^{*}$ \\
\hline \multirow[t]{2}{*}{ 2. ATT } & $1^{\text {st }}$ & 1 & .26 & -.02 & $.31^{*}$ & -.04 & $.32 *$ & -.24 & .13 & $.36^{* *}$ & $.57 * *$ \\
\hline & $2^{\text {nd }} \& 3^{\text {rd }}$ & & $.58^{*}$ & -.06 & $.50^{*}$ & .11 & $.53^{*}$ & .21 & .21 & $.54^{*}$ & $.58^{*}$ \\
\hline \multirow[t]{2}{*}{ 3. $\mathrm{CON}$} & $1^{\text {st }}$ & & 1 & .21 & $.43^{* *}$ & $.27^{*}$ & $.48^{* *}$ & .05 & $.46^{* *}$ & $.52^{* *}$ & .03 \\
\hline & $2^{\text {nd }} \& 3^{\text {rd }}$ & & & $.50 *$ & $.69 * *$ & $.50 *$ & $.80^{* *}$ & $.54^{*}$ & $.76^{* *}$ & $.53^{*}$ & .17 \\
\hline \multirow[t]{2}{*}{ 4. INP } & $1^{\text {st }}$ & & & 1 & $.45^{* *}$ & $.38^{* *}$ & $.26^{*}$ & $.38^{* *}$ & $.32 *$ & .11 & -.03 \\
\hline & $2^{\text {nd }} \& 3^{\text {rd }}$ & & & & $.57^{*}$ & $.79 * *$ & .31 & $.66^{* *}$ & $.75^{* *}$ & .08 & -.21 \\
\hline \multirow[t]{2}{*}{ 5. MOT } & $1^{\text {st }}$ & & & & 1 & $.34^{* *}$ & $.54^{* *}$ & $.34^{* *}$ & $.55^{* *}$ & $.53^{* *}$ & $.27^{*}$ \\
\hline & $2^{\text {nd }} \& 3^{\text {rd }}$ & & & & & $.55^{*}$ & $.60^{* *}$ & $.58^{*}$ & $.76^{* *}$ & $.58^{*}$ & .08 \\
\hline \multirow[t]{2}{*}{ 6. SFT } & $1^{\text {st }}$ & & & & & 1 & -.12 & $.42^{* *}$ & $.43^{* *}$ & -.13 & -.18 \\
\hline & $2^{\text {nd }} \& 3^{\text {rd }}$ & & & & & & .25 & $.86^{* *}$ & $.59 *$ & .01 & -.02 \\
\hline \multirow[t]{2}{*}{ 7. SMI } & $1^{\text {st }}$ & & & & & & 1 & -.14 & $.39 * *$ & $.70^{* *}$ & .13 \\
\hline & $2^{\text {nd }} \& 3^{\text {rd }}$ & & & & & & & .33 & $.68^{* *}$ & $.67^{* *}$ & .26 \\
\hline \multirow[t]{2}{*}{ 8. STA } & $1^{\text {st }}$ & & & & & & & 1 & $.29 *$ & -.01 & -.11 \\
\hline & $2^{\text {nd }} \& 3^{\text {rd }}$ & & & & & & & & $.62^{* *}$ & .07 & .05 \\
\hline \multirow[t]{2}{*}{ 9. TMT } & $1^{\text {st }}$ & & & & & & & & 1 & $.31^{*}$ & -.04 \\
\hline & $2^{\text {nd }} \& 3^{\text {rd }}$ & & & & & & & & & $.53^{*}$ & -.08 \\
\hline \multirow[t]{2}{*}{ 10. TST } & $1^{\text {st }}$ & & & & & & & & & 1 & $.35^{* *}$ \\
\hline & $2^{\text {nd }} \& 3^{\text {rd }}$ & & & & & & & & & & $.54^{*}$ \\
\hline 11. FMS & $1^{\text {st }}$ & & & & & & & & & & 1 \\
\hline
\end{tabular}

* Significant at the .05 level; ** Significant at the .01 level.

Correlation between SRL Strategies and Math Performance: Table 4 shows the Pearson correlations among the LASSI scales and math performance for the two groups of international students. For firstsemester international students, all significant positive correlations are ranged from .26 (Information Processing vs. Selecting Main Ideas) to .70 (Selecting Main Ideas vs. Test Strategies). For second- and third-semester international students, significant positive correlations are ranged from .50 (Attitude vs. Motivation, Concentration vs. Information Processing, and Concentration vs. Self-Testing) to .86 (SelfTesting vs. Study Aids), and only one significant negative correlation, which is -.51 (Anxiety vs. Information Processing). For first-semester international students, Attitude, Motivation and Test Strategies are significantly and positively correlated to their math performance, while for second- and 
third-semester international students, Anxiety, Attitude and Test Strategies are significantly and positively correlated to their math performance.

Predicting Math Performance by SRL Strategies: The result of regression analysis for each of the semester groups can be seen in Table 5. For the group of first-semester international students, the F test suggests that the regression model is significantly fitted into the data with $F(10,45)=4.287, p<.01$ and $\mathrm{R}^{2}=.488$, adjusted $\mathrm{R}^{2}=.374$. Math performance of first-semester international students is significantly and positively predicted by Attitude and Test Strategies. For the group of second- and third-semester international students, their $\mathrm{R}^{2}=.876$ and adjusted $\mathrm{R}^{2}=.628$ are higher than those of the previous group. The $\mathrm{F}$ test suggests that the regression model for the second group is not significantly fitted into the data at the .05 level with $F(10,5)=3.536, p=.088$, but the fit is significant at the .10 level. The regression result shows that none of the LASSI scales significantly predicts math performance of second- and thirdsemester international students at the .05 level.

Table 5: Coefficients of Regression Model for First-Semester International Students and Secondand Third-Semester International Students

\begin{tabular}{|c|c|c|c|c|c|c|c|c|c|c|}
\hline \multirow{2}{*}{$\begin{array}{l}\text { Variabl } \\
\text { e }\end{array}$} & \multicolumn{5}{|c|}{$1^{\text {st }}$ Semester } & \multicolumn{5}{|c|}{$2^{\text {nd }} \& 3^{\text {rd }}$ Semesters } \\
\hline & B & S.E & Beta & $\mathbf{t}$ & $\mathbf{p}$ & B & S.E & Beta & $\mathbf{t}$ & $\mathbf{p}$ \\
\hline ANX & -.77 & .69 & -.17 & -1.11 & .272 & 2.89 & 2.16 & 1.05 & 1.34 & .238 \\
\hline ATT & 1.99 & .49 & .50 & 4.04 & $.000^{* *}$ & 1.86 & 1.00 & .54 & 1.85 & .123 \\
\hline CON & -.25 & .82 & -.05 & -.30 & .765 & -2.80 & 1.74 & -.75 & -1.61 & .169 \\
\hline INP & .23 & .68 & .04 & .33 & .740 & 3.59 & 2.09 & .85 & 1.72 & .147 \\
\hline MOT & 1.52 & .83 & .32 & 1.82 & .075 & -2.31 & 1.82 & -.49 & -1.27 & .261 \\
\hline SFT & -1.14 & .74 & -.24 & -1.54 & .131 & -.35 & 1.97 & -.09 & -.18 & .867 \\
\hline SMI & -1.54 & .79 & -.36 & -1.95 & .058 & -.59 & 2.34 & -.13 & -.25 & .812 \\
\hline STA & -.17 & .70 & -.04 & -.25 & .807 & 3.42 & 1.61 & .98 & 2.12 & .087 \\
\hline TMT & -.55 & .92 & -.09 & -.60 & .552 & -2.19 & 2.51 & -.51 & -.87 & .424 \\
\hline TST & 1.62 & .79 & .36 & 2.04 & $.047^{*}$ & 1.65 & 1.90 & .49 & .87 & .424 \\
\hline
\end{tabular}

${ }^{*}$ Significant at the .05 level; ${ }^{* *}$ Significant at the .01 level.

Discussion: The similarities between first-semester international students and second- and thirdsemester international students are both groups achieve the same math success and exercise the same SRL strategies in their goal to achieve math success, despite second- and third-semester international students are more familiar to the academic setting than first-semester international students. Moreover, the finding of the study indicates that the association between the use of SRL strategies and math performance can be found among international students who are widely diversified in terms of educational and cultural backgrounds. First of all, the result shows that both groups' math performance is significantly and positively associated with attitude towards academic tasks and test taking strategies, in which this finding is not consistent with the previous studies (Belcheir, 2002; MacNamara \& Penner, 2005; Wadsworth et al., 2007). One possible explanation for the inconsistency is the previous studies involve mathematical subjects at university level where they have different emphasis in learning of math. Motivation is the other SRL strategy that is significantly and positively associated with first-year international students' math performance, which is in accordance with these studies (Belcheir, 2002; MacNamara \& Penner, 2005; Wadsworth et al., 2007). The consistency suggests that high math achievers possess high level of motivation not only appeared at university level but also occurred at pre-university level. On the other hand, second- and third-semester international students' math performance is also significantly and positively associated with anxiety towards tests. The finding is contrast with MacNamara and Penner's (2005) study, in which a negative correlation is found in the previous study. One possible explanation is that the mathematical subject at the pre-university program is too examorientated as its assessment format involves topic tests and final exam. In addition, thereby, makes second- and third-semester international students worry about their study, but drive them to achieve better academic results. However, a further research is to be carried out to investigate the positive correlation between second- and third-semester international students' math performance and anxiety towards tests.

Math performance among first-semester international students is significantly predicted by attitude towards academic tasks and test taking strategies. However, the result is not consistent with the previous studies (Belcheir, 2002; Wadsworth et al., 2007). The inconsistency may due to the emphasis on SRL strategies as well as their achieving goal are different between undergraduate students and pre- 
university international students. The result also shows that about $50 \%$ of the variation of their math performance is explained by the use of SRL strategies, and another half of the math variation is explained by other factors, which are not included in the study. A further research on pre-university international students' math performance is to be conducted to include other factors such as English proficiency and their academic achievement prior to joining the pre-university program. On the other hand, no SRL strategies significantly predicts math performance of second- and third-semester international students, which is contrast with Belcheir's (2002) and Wadsworth et al.'s (2007) studies. However, the variation of math performance of this group is highly explained by the use of SRL strategies. This suggests that the exercise of these SRL strategies among second- and third-semester international students will contribute tremendously to their math success.

\section{Implications and Recommendations}

The implication to academic staff is that they should be aware about the importance of good attitude towards academic tasks and good test taking strategies to math performance among international students. In addition, for international students who are in their first semester, academic staff of the subject should motivate them during math lessons as the high level of motivation will lead to better results in math. For international students who are in their second and third semesters, academic staff should try not to create a situation that make them worry towards their study even though a positive correlation is found between math performance and anxiety towards tests. Perhaps, training on how to use efficient and appropriate SRL strategies should be provided to international students particularly those in their second and third semesters as the use of SRL strategies contributes substantially to their math performance. The first limitation of the study is the sample size, which is considered as small. Secondly, the result of the study may not be use directly by other pre-university programs offered at institutions of higher education in Malaysia as the assessment format and academic setting of the MUFY program may differ from others, but it can be served as guidance for similar studies. Finally, the selfreported items answered by students may inflate some of the LASSI scales, and subsequently cause misleading results in the analyses.

\section{References}

Anthony, G. (1996). When Mathematics Students Fail to Use Appropriate Learning Strategies. Mathematics Education Research Journal, 8(1), 23-37.

Baharun, R., Awang, Z. \& Padlee, S. F. (2011). International Students Choice Criteria for Selection of Higher Learning in Malaysian Private Universities. African Journal of Business Management, 5(12), 47044714.

Bakar, K. A., Tarmizi, R. A., Mahyuddin, R., Elias, H., Wong, S. L. \& Ayub, A. F. M. (2010). Relationships between University Students' Achievement Motivation, Attitude and Academic Performance in Malaysia. Procedia Social and Behavioral Sciences, 2(2), 4906-4910.

Belcheir, M. J. (2002). What Predicts Success in Intermediate Algebra? Research Report 2002-06 (Boise State University). [Online] Available: http://www.boisestate.edu/iassess/reports/2002/RR200206.pdf (November, 8, 2010)

British Council. (2008). International Student Mobility in East Asia: Executive Summary. [Online] Available:http://www.eahep.org/web/images/Malaysia/bc\%20-\%20asia\%20student\% 20mobility\%20-\%20summary.pdf (October, 12, 2011)

Credé, M. \& Kuncel, N. R. (2008). Study Habits, Skills, and Attitudes: The Third Pillar Supporting Collegiate Academic Performance. Perspectives on Psychological Science, 3(6), 425-453.

Dahari, Z. \& Abduh, M. (2011). Factors Influencing International Students' Choice towards Universities in Malaysia. African Journal of Business Management, 5(26), 10615-10620.

Hulick, C. \& Higginson, B. (1989). The Use of Learning and Study Strategies by College Freshmen. Paper presented at the Annual Meeting of the Mid-South Educational Research Association, Little Rock, Arkansas, November, 1989.

Jani, R. \& Zubairi, Y. Z. (2010). International Students' Views of Malaysian Higher Education. Paper presented at Internationalization and Marketing of Higher Education Malaysia Seminar, Putrajaya, Malaysia, 17 June 2010.

Kaplan, A. (2008). Clarifying Metacognition, Self-Regulation, and Self-Regulated Learning: What is the Purpose? Educational Psychology Review, 20(4), 477-484.

MacNamara, D. \& Penner, K. (2005). First-year Math Students: Using Study Skills and Motivation to Predict Academic Success (Kwantlen University College). [Online] Available: 
http://www.mykwantlenpolytechnicuniversity.com/_shared/assets/Math_Retention_Study2878.p df (November, 2, 2010)

Malpass, J. R., O'Neil, H. F. \& Hocevar, J. D. (1999). Self-Regulation, Goal Orientation, Self-Efficacy, Worry, and High-Stakes Math Achievement for Mathematically Gifted High School Students. Roeper Review, 21(4), 281-288.

Ministry of Higher Education. (2008). Perangkaan Pengajian Tinggi Malaysia Tahun 2008. [Statistics of Higher Education of Malaysia Year 2008.] [Online] Available: http://www.mohe.gov.my/web_statistik/Buku_Perangkaan_2008.pdf (September, 19, 2011)

Ministry of Higher Education. (2009). Perangkaan Pengajian Tinggi Malaysia Tahun 2009. [Statistics of Higher Education of Malaysia Year 2009.] [Online] Available: http://www.mohe.gov.my/web_statistik/satistik_2009.htm (September, 19, 2011)

Ministry of Higher Education. (2010). Perangkaan Pengajian Tinggi Malaysia Tahun 2010. [Statistics of Higher Education of Malaysia Year 2010.] [Online] Available: http://www.mohe.gov.my/web_statistik/perangkaan_2010.pdf (September, 19, 2011)

Pokay, P. \& Blumenfeld, P. C. (1990). Predicting Achievement Early and Late in the Semester: The Role of Motivation and Use of Learning Strategies. Journal of Educational Psychology, 82(1), 41-50.

Purdie, N., Hattie, J. \& Douglas, G. (1996). Student Conceptions of Learning and Their Use of Self-Regulated Learning Strategies: A Cross-Cultural Comparison. Journal of Educational Psychology, 88(1), 87100.

Reaser, A., Prevatt, F., Petscher, Y. \& Proctor, B. (2007). The Learning and Study Strategies of College Students with ADHD. Psychology in the Schools, 44(6), 627-638.

Roslyn Kunin \& Associates. (2009). Economic Impact of International Education in Canada: Final Report. [Online]Available:http://www.international.gc.ca/education/assets/pdfs/RKA_IntEd_Report_eng. pdf (March 21, 2012)

Schunk, D. H. \& Zimmerman, B. J. (2008). Motivation and Self-Regulated Learning: Theory, Research, and Applications, New York: LEA.

Sirat, M. (2006). Malaysia. In SEAMEO (Ed.), Higher Education in South-East Asia (pp.101-136). Bangkok: UNESCO Asia and Pacific Regional Bureau for Education.

Sirat, M. (2008). The Impact of September 11 on International Student Flow into Malaysia: Lessons Learned. International Journal of Asia-Pacific Studies, 4(1), 79-95.

Sivalingam, G. (2006). Privatization of Higher Education in Malaysia. Forum on Public Policy. [Online] Available: http://www.forumonpublicpolicy.com/archive07/sivalingam.pdf (February, 20, 2012).

Stoynoff, S. (1997). Factors Associated with International Students' Academic Achievement. Journal of Instructional Psychology, 24(1), 56-68.

Valiente, C. (2008). Are Students Using the 'Wrong' Style of Learning? A Multicultural Scrutiny for Helping Teachers to Appreciate Differences. Active Learning in Higher Education, 9(1), 73-91.

Wadsworth, L. M., Husman, J., Duggan, M. A. \& Pennington, M. N. (2007). Online Mathematics Achievement: Effects of Learning Strategies and Self-Efficacy. Journal of Developmental Education, 30(3), 6-14.

Weinstein, C. E., Palmer, D. R. \& Shulte, A. C. (2002). LASSI: Learning and Study Strategies Inventory, Second Edition, $\mathrm{H} \& \mathrm{H}$ Publishing Inc.

Wolters, C. A. \& Pintrich, P. R. (1998). Contextual Differences in Student Motivation and Self-Regulated Learning in Mathematics, English, and Social Studies Classrooms. Instructional Science, 26(1-2), 2747.

Yip, M. C. W. \& Chung, O. L. L. (2005). Relationship of Study Strategies and Academic Performance in Different Learning Phases of Higher Education in Hong Kong. Educational Research and Evaluation, 11(1), 61-70.

Yusoff, Y. M. \& Chelliah, S. (2010). Adjustment in International Students in Malaysian Public University. International Journal of Innovation, Management and Technology, 1(3), 275-278. 